\title{
The management of pediatric pain and the perception of the nursing team in light of the Social Communication Model of Pain
}

\author{
O manejo da dor pediátrica e a percepção da equipe de enfermagem à luz do Modelo Sócio \\ Comunicativo da Dor
}

Stela Cruz Faccioli ${ }^{1}$, Mauren Teresa Grubisich Mendes Tacla¹, Edilaine Giovanini Rossetto ${ }^{1}$, Neusa Collet ${ }^{2}$

DOI 10.5935/2595-0118.20200009

\section{ABSTRACT}

BACKGROUND AND OBJECTIVES: Pain is a multidimensional experience, and its management depends on both the professional's sensitivity and their ability to choose strategies for measurement and relief. The nursing team plays a fundamental role in this process since the assessment of pain in a systematic way provides the right therapeutic measures to the child. The present study aimed to evaluate pain and analgesia in the medical records and to understand the perception of the nursing team regarding the management of pain in hospitalized children.

METHODS: Qualitative, descriptive, exploratory research carried out in a tertiary level state university hospital. Data collection included patients hospitalized in a pediatric inpatient unit and a semi-structured interview with 24 members of the nursing team. A thematic analysis proposed by Minayo was used for data analysis. The analysis was performed following the Social Communication Model of Pain.

RESULTS: Eighty medical records were analyzed, and although pain is considered the fifth vital sign, most of the nurse prescriptions for pain remain blank in the medical records The participants' reports resulted in three categories: the naturalness of the pain in hospitalized children; the responsibility of the nursing team before the $5^{\text {th }}$ vital sign; pain management.

CONCLUSION: Paying attention to the painful process of a child requires some skills from the professional to identify, assess, use proper instruments, understand the feelings involved in the process, and entail care in the prioritization of pediatric pain management.

Keywords: Nursing records, Pain, Pain measurement, Pediatric nursing.

Stela Cruz Faccioli - (Dhttps://orcid.org/0000-0001-8021-0750;

Mauren Teresa Grubisich Mendes Tacla - (Dhttps://orcid.org/0000-0001-8928-3366;

Edilaine Giovanini Rossetto - (Dhttps://orcid.org/0000-0002-0996-5154;

Neusa Collet - D https://orcid.org/0000-0002-4795-0279.

1. Universidade Estadual de Londrina, Departamento de Enfermagem, Londrina, PR, Brasil. 2. Universidade Federal da Paraíba, Departamento de Pós-Graduaçāo em Enfermagem, Joâo Pessoa, PB, Brasil.

Submitted on July 16, 2019.

Accepted for publication on December 16, 2019.

Conflict of interests: none - Sponsoring sources: none.

Correspondence to:

Rua Maria Angela de Oliveira Esterque, 909, casa 20 - Jardim Santa Fé

19063-747 Presidente Prudente, SP, Brasil.

E-mail: stelafaccioli@hotmail.com

(C) Sociedade Brasileira para o Estudo da Dor

\section{RESUMO}

JUSTIFICATIVA E OBJETIVOS: A dor é uma experiência multidimensional e seu tratamento depende tanto da sensibilidade dos profissionais quanto de sua competência na escolha das estratégias para mensuração e alívio. A enfermagem possui papel fundamental nesse processo, sendo que a avaliaçáa da dor, de maneira sistematizada, proporciona à criança medidas terapêuticas adequadas. $\mathrm{O}$ objetivo deste estudo foi analisar os registros sobre a avaliação da dor e analgesia nos prontuários e compreender a percepçáo da equipe de enfermagem quanto ao tratamento da dor da criança hospitalizada.

MÉTODOS: Pesquisa qualitativa, descritiva exploratória realizada em um hospital universitário estadual e de nível terciário. A coleta de dados contemplou prontuários de crianças hospitalizadas em unidade de internação pediátrica e entrevista semiestruturada individual com 24 membros da equipe de enfermagem. Para a análise dos dados, utilizou-se a análise temática proposta por Minayo. A análise foi realizada à luz do marco conceitual Social Communication Model of Pain.

RESULTADOS: Foram analisados 80 prontuários, e mesmo com a dor sendo considerada como quinto sinal vital, a maior parte dos registros da dor em prescrições de enfermagem permaneceu em branco. Os relatos das participantes resultaram em três categorias: naturalização da dor na criança hospitalizada; responsabilização da enfermagem diante do quinto sinal vital; manejo da dor.

CONCLUSÁO: Prestar o cuidado frente ao processo doloroso de uma criança exige habilidades do profissional para identificar, avaliar, utilizar instrumentos adequados, compreender sentimentos envolvidos no processo e significar o cuidado na priorizaçáo da assistência à dor pediátrica.

Descritores: Dor, Enfermagem pediátrica, Mensuração da dor, Registros de enfermagem.

\section{INTRODUCTION}

The International Association for the Study of Pain (IASP) defines pain as "an unpleasant sensory and emotional experience associated with actual or potential tissue damage or described in terms of such damage"1. Pain is always subjective, as each individual learns the application of the term through experiences related to previous injuries ${ }^{2}$. Even with advances in the scientific evidence on pediatric pain, children are still considered the most vulnerable group and exposed to painful experiences during hospitalization ${ }^{3}$. 
Since pain is a multidimensional phenomenon and considering the value of the complaint and its subjectivity in humanized care, pain was included as the $5^{\text {th }}$ vital sign in order to alleviate suffering and ensure better patient care ${ }^{4}$.

A child in pain may be exposed to the destabilization of other vital signs (SSVV), and the verification of pain as the $5^{\text {th }}$ vital sign allows the identification of discomfort and instability signs. However, in most cases, it was observed that pain assessment and control are not yet incorporated into the nursing team's routine since only the classic verification of SSVV occurs in an institutionalized way ${ }^{5}$.

Children have particularities in pain manifestation; therefore, professionals need to understand the stages of their development and the variations of age groups to be able to use assessment instruments and pain management strategies according to these particularities ${ }^{6}$.

In addition, it is necessary to understand the specifics of multiple causal factors, in addition to tissue disease ${ }^{7}$. Considering this, pain is now understood as a distressing experience associated with real or potential injury to the tissue with sensory, emotional, cognitive, and social components ${ }^{2}$.

Thus, it is only possible to understand the painful phenomenon of hospitalized children when we recognize that pain is subjective, i.e., each child experiences and expresses it individually. So, it is up to the person who is evaluating this pain to understand the meaning that the child attributes to his/her own pain in order to be able to perform appropriate management for each situation. Based on these principles, bearing in mind that pain management is directed both to those who feel it and to those who assist, there are models that seek to understand the pain in its multidimensionality. One of these models, adopted as a conceptual framework for this research, is the Social Communication Model of Pain (SCMP) ${ }^{8}$.

SCMP was developed aiming at understanding the pain episode integrating the biological, psychological, and social levels. The model is based on a linear time sequence of tissue injury or stress. Therefore, the pain experience may suffer inferences regarding the pain interpretation by those who feel it and by the person who can influence it ${ }^{8}$.

Decisions about pain management are related to the professional's assessment of a situation and the role of the nursing team in pain management, which includes assessment, plan for pharmacological and non-pharmacological strategies, pain record and implementation, and evaluation of the patient's response to interventions?.

Considering that pain management involves, from the moment of its identification in the nursing record, the multidimensional aspects of those who feel it and the professional who assists and the use of appropriate instruments for its evaluation, this study permeates the question of how the nursing team is perceiving the pain management of hospitalized children.

In this context, the objective was to analyze the nursing and medical teams' recordings regarding the assessment of pediatric pain and to identify the perception of the nursing team regarding the pain management of hospitalized children in the light of the Social Communication Model of Pain.

\section{METHODS}

Qualitative descriptive research based on SCMP. The research was carried out in a Pediatric Inpatient Unit (UIP) of a state, public, and tertiary-level university hospital in southern Brazil.

Data collection was carried out between 2016 and 2017, with information acquired in two stages: the first on the nursing and medical teams' recordings regarding the assessment of pain in hospitalized children and prescriptions of relief measures, contemplating, through an instrument developed by the researcher, the pain recording as the $5^{\text {th }}$ vital sign; the pain recording in medical prescription and nursing notes; the prescribed analgesia and the analgesia performed by the nursing team.

The data from the first stage were collected retrospectively, referring to the period from August to October 2016, the selected period taking into account the highest occupancy rate of the unit in that year. Each medical record, regardless of the length of hospital stay, was analyzed for seven days or until hospital discharge. The sample referring to medical records had as inclusion criteria the medical records of children who were hospitalized in the UIP for at least 48 hours; the presence of medical prescription; the presence of nursing notes. Medical records of children who died were excluded.

The sample resulted in 80 medical records and 360 medical prescriptions and nursing notes.

For data analysis, the Microsoft Office Excel ${ }^{\circ}$ Software was used, in which a spreadsheet was created with the data, and inferences were made about them.

The second stage of data collection, based on the SCMP, included data on the characterization of participants and issues related to pain naturalization; pain recognition as a vital sign, knowledge regarding the evaluation scales, and the choice of measures for pain relief. The data were collected through interviews semi-structured by the chief researcher, with an individual approach in a private place with an average duration of 15 minutes, being captured by a digital recorder for later transcription in full.

The sample had as inclusion criteria having experience with pediatric nursing for at least one year, and those who were on vacation or leave during the collection period were excluded from the sample. The sample comprised 15 professionals from the nursing team, from different work shifts.

For data analysis, thematic analysis was used in which, after an exhaustive reading of the material, units of meaning and nuclei of meaning emerged, which meant something in relation to the analyzed object. The three stages of data analysis were followed: pre-analysis, material exploration, and treatment of the results obtained and interpretation ${ }^{10}$.

After analyzing the data, three categories emerged: pain naturalization in hospitalized children, nursing accountability before the $5^{\text {th }}$ vital sign, pain management.

The ethical precepts were followed when signing the Free and Informed Consent Term (FICT), and for reasons of secrecy and privacy, the names were replaced by the professional class abbreviation followed by a number, following an increasing order as the interviews were conducted. 
The research project was submitted to the Human Research Ethics Committee of the State University of Londrina, based on resolution 510/2016 of the National Health Council (Brazil, 2016). It obtained favorable opinion No. 1.816.082, CAAE 61380316.5.0000.52.

\section{RESULTS}

The medical records analysis showed that $56 \%(\mathrm{n}=45)$ of the hospitalized children in the selected period were male and 44\% $(\mathrm{n}=35)$ female. Regarding the age, it varied between 29 days and five years old. The average length of hospital stay was five days, and the most prevalent diagnoses were: preterm newborns (PTNB) $(n=16)$ and injuries and consequences from external causes $(\mathrm{n}=11)$.

Regarding the nursing team records, it was found that $90 \%$ $(\mathrm{n}=324)$ had pain as zero or blank. From this number, $57 \%$ $(n=205)$ had a pain episode record, and a drug was administered according to a medical prescription.

As for medical prescriptions, $60 \%(\mathrm{n}=216)$ contained more than one analgesic option and it was found that $80 \%(\mathrm{n}=288)$ included dipyrone, 75\% ( $\mathrm{n}=270)$ paracetamol, 25\% ( $\mathrm{n}=90)$ opioids (morphine and tramadol), 2\% ( $\mathrm{n}=7)$ ketamine and 2.7\% ( $\mathrm{n}=10)$ had no prescribed analgesia.

\section{Pain management from the nursing team perspective}

The participants worked for more than 10 years in the pediatric area, and the mean age was 46 years old. The report's analysis resulted in three categories: pain naturalization in hospitalized children, nursing accountability before the $5^{\text {th }}$ vital sign, pain management.

\section{Category 1 - Pain naturalization in hospitalized children}

In this category, is expressed the personal experience of pain contemplated in the SCMP, the biological substrates for pain perception, the life history that can impact and determine the meaning and affective understanding of pain. The pain naturalization reflects the perception that each professional brings with them, their values and objectives, and may be associated with professional training and/or previous experiences that marked their path.

When asked about the pain presence during hospitalization, some professionals believed the fact that the child is hospitalized makes this natural, following the reasoning that if the child is hospitalized, he/she will consequently feel pain.

If helshe is hospitalized, it is because helshe has a health problem... helshe will probably experience some pain. Helshe is already expected to feel pain. I think it's normal (AUX04).

As little as possible... but certain pains are beyond our control. We have nothing to do (TECO8).

I think so, depending on what helshe has, if this is cause for pain, it is normal for him/her to cry and feel pain. I have experienced this a lot with children, and I know it is normal (AUXO2).

On the other hand, some participants reported that the hospitalized child should not experience pain because professionals must adopt measures, and the institution must provide what is necessary to relieve the child's pain.
No, there is no way helshe should be in pain. If helshe is in the hospital, helshe is not intended to feel pain. It is not normal to feel pain if it can be relieved. This is not what I believe in (TECO9).

I think it's like that, one concern we have is that the hospitalized child cannot feel pain. There is a child admitted to the hospital with all the infrastructure, and we cannot leave him/her in pain. At least, that's not how I learned (ENF04).

Category 2 - Nursing accountability before the $5^{\text {th }}$ vital sign In the second category, the relationship between the professional's perception before pain and extrinsic factors was observed, as proposed by the SCMP, i.e., the model recognizes complexity through multiple input sources, including not only expressive behaviors of the person in pain but also a range of contextual factors in which observers participate.

When asked about pain recognition as a vital sign, the reports demonstrated that pain assessment was not prioritized as the $5^{\text {th }}$ vital sign, referring to work overload and other tasks as a priority.

Yes, I have been doing. I'll be very sincere. Lately, I have been insufficient because I'm very busy. You don't have time for anything, you have to take one here, and medicate the other there. Then automatically, as you saw the vital signs before, then you put zero. Because like this, I was in the infirmary, so for me, the most important thing is to medicate, run after the medication needed [...] one cries with pain, and then you change the bandage. Now that you asked, I realized I let it go unnoticed (AUXO1).

I know that pain can be considered as a vital sign equal to temperature, heart rate, but when in a hurry with all the duties, I end up letting it go, and I only write it down when the child really cries in pain (TECO8).

Yes, inside the hospital, it is because it is like this, whenever we are asked, we take action, so I think so. And then I write it down in both prescriptions, sometimes I don't write in the back [space dedicated to the recording of vital signs], but in the front, I always write it down. I only write it down when helshe was in pain. We even know that we need to take notes at the time of the other signs, but there is a lot of demand here (AUXO2).

\section{Category 3 - Pain management}

The third category is related to the intrinsic and extrinsic factors influencing the professional regarding the pain management proposed by the SCMP, and the model attributes to the management a complexity related to the experience of pain; the verbal and non-verbal variable; the physiological manifestations of pain; observers' reactions when they strive to assess and understand the child's pain; and the complex judgments associated with decisions to perform care or not.

The following reports referring to the pain's identification and relief demonstrate a sequence of perceptions, from the moment of observation of the painful phenomenon to the choice of the strategy to be used. It is observed that pain is not idealized as a vital sign, passing through the idea of recording only in moments of pain and ending with the choice of the pharmacological strategy as the only option.

I really assess the pain. I try, right? I look at the child, I think about what helshe may be feeling, I try to understand if it may be drama, 
hunger, then when I see that it is not like that, I know it is a pain, right? I can tell when it is pain with the experience I already have, for so many years seeing children in pain (ENFO3).

I write it down at the time of vital signs... because usually the child is calm and when helshe feels pain, then I write if the pain degree is one, two, three. But to tell you the truth, I do not always remember noting the pain, no, it goes unnoticed (AUX05).

I always do the simplest. If it is an uncomplicated child, if it is not written what it is, to begin with. Then if it is written, I do it as prescribed. For example, today, dipyrone and morphine were prescribed for the boy, then I start with dipyrone first (AUXO3).

As for pain assessment, the SCMP emphasizes the relationship between training and education that the professional brings with $\mathrm{him} / \mathrm{her}$, standardized instruments in the institution, and the professional's perception. When asked about the instruments used, it was observed that professionals base pain assessments on their previous knowledge and perceptions.

I have used a scale like this; the child is tearful, uncomfortable. It's used more in small children, right? When helshe is older, helshe can speak to us himselflherself (TECO7).

As little babies, we can see by their behavior. When they move a lot, they twist, they get very restless. More because of their irritation. When they are in pain, have a fever, then everything is mixed up (TECO4).

Like this, with a bigger child, you ask, are you in little pain, in average pain or a lot of pain? Then you can evaluate more or less... Little pain is less than five; the average pain is about five; a lot of pain is considered 10 (ENFO2).

The reports regarding interventions to relieve the child's pain permeated non-standardization and were exclusively pharmacological.

I start with the weakest. If there are morphine and dipyrone, I will make the dipyrone first. Then, if it doesn't provide relief, we do the strongest one (AUX08).

I start with paracetamol, then dipyrone, and, in the last case, morphine. Morphine is stronger, much stronger (TEC10).

If a child is not post-op, I start with dipyrone. If it is a child who is in the immediate postoperative period, I already think it has to be a dose of morphine or tramadol that is prescribed at medical discretion. Then you call the nurse and ask if you can do it or not. And if the doctor says no, then you give paracetamol. This is the criterion (TEC011).

\section{DISCUSSION}

The data obtained in this study indicated that even with the implantation of pain as the $5^{\text {th }}$ vital sign since 2007, the nursing records related to pain assessment are still incomplete, and it was observed that there is no standardization of criteria for medical prescriptions elaboration. Besides, it was clear that professionals are aware of the importance of assessing pain in children. However, they use their own criteria and do not consider it as the $5^{\text {th }}$ vital sign.
SCMP proposed by Craig ${ }^{8}$ explains four sequenced steps, conceptually distinct, but interactive, after an initial painful event: (1) the child's pain experience, (2) the child's pain expression, (3) pain assessment by a caregiver, and (4) actions taken (or not) by others that would impact the child's pain.

Although pain is subjective, behavioral activity allows for observable inferences. Children's demonstrations of pain cause spontaneous reactions in observers, as well as the potential for empathy and clinical judgment ${ }^{2}$.

The reports demonstrate that professionals naturalize pain during hospitalization, which does not make them cruel, but it corroborates the SCMP's statement that the professionals' beliefs directly interfere in the process of decoding pain.

Naturalizing or not pain goes beyond being empathetic, permeates acts, behaviors, beliefs, and attitudes of nursing professionals who need to be sensitive to the child's suffering and understand that they can react physically and emotionally to the painful process ${ }^{11}$. As evidenced in the reports, professionals start from their own conceptions for assessing pain and the expression of pain determines mainly, but not exclusively, the observer's assessment, and this reaction, in turn, will have an impact on pain management, depending on the reaction.

Among the factors that the observer will evaluate are the child's expressions and the component of the model that encompasses the child's expression and the caregiver's evaluation, which are the core and exemplifies the belief that pain is fundamentally a social experience ${ }^{2}$.

Pain valuation by the professional and institution contemplates the situational context of interpersonal factors and the professional aspect of intrapersonal factors proposed by the SCMP. In the UIP of this study, pain was instituted as the $5^{\text {th }}$ vital sign to incorporate the routine of the nursing team, since the presence of pain can trigger physiological changes in the child.

However, the reports demonstrated the prioritization of other tasks when assessing pain, corroborating the statement that nursing care focused on fulfilling duties leaves aside the meaning in nursing care from the perspective of showing zeal, attention, solicitude ${ }^{12}$.

Thinking about the priority in care is to understand that the role of the nursing team goes beyond the painkillers' administration, it is the understanding of the pain multidimensionality of those who feel it and those who assist it. It is to redefine nursing care for children in pain to ensure their well-being, making hospitalization less traumatic ${ }^{13}$.

Pediatric pain management includes pain recognition to the moment when the professional defines which strategies to use to relieve it. For this sequence of events to be carried out properly, the nursing professional needs to understand the importance of his/her role in this process and recognize how prepared he/she is to carry out this management ${ }^{14}$.

This preparedness is evidenced in the SCMP as the professional training involved in the professional's intrapersonal factors, which in practice is illustrated as transmitted content, institutional training, and previous knowledge ${ }^{8}$.

Adequate pain management begins with the assessment and understanding of problems taking into account the patient's uni- 
queness. A study carried out with 261 nurses from three public hospitals showed that $88.8 \%$ believe it is important to assess and document pain, while $11.2 \%$ believe it is not important. However, $72 \%$ reported not carrying out the assessment using standardized protocols and scales and attributed this to the lack of training and previous experiences with hospitalized children?. Likewise, the UIP nursing team believes in the importance of pain assessment and documentation, but its practice is based on their own habits, beliefs, and attitudes to the detriment of available scientific knowledge and institutional standards.

A study carried out at the concerned UIP in 2015 observed that during the subsequent years, with the establishment of pain as a vital sign, training by professionals from the education center, and training by resident nurses to use the instruments was provided. However, professionals continue to justify not using it because they do not have knowledge ${ }^{4}$.

Also related to the UIP, in 2011, a study analyzed 385 medical records of hospitalized children and found that $51.4 \%$ did not have their pain intensity quantified ${ }^{16}$. Likewise, a study carried out $^{3}$ in a Canadian hospital, found that in a UIP, within 24 hours, there was no documentation of pain assessment.

$\mathrm{SCMP}^{8}$ refers to the pain assessment and recording step as the third sequential step of the four existing ones, conceptually distinct, but interactive, after an initial painful event. The proposed model states that by not performing a reliable assessment or recording it, it can influence the fourth step, which consists of taking action in the face of pain.

As in all process stages, judgments of caregivers and decisions to offer and provide care are mutually influential. The actions taken by a caregiver can also affect their assessment. Besides, how a caregiver manages a child's pain can also return to the beginning of the sequence and impact how a child's pain experience is created ${ }^{17}$.

Faced with the actions that the professional decides to take and considering that the analgesia administration is the last step of the linear sequence proposed by the SCMP, medical prescriptions also play an important role, since professionals choose certain pharmacological therapies, and need to be adequate to the age group and diagnosis.

In the reports and medical prescriptions analyzed, there was a lack of standardization in the choice of drugs, both by the nursing team and by the medical team when prescribing analgesics. In contrast to this finding, in the guidelines on the pharmacological treatment of pain in children, there was an update of the analgesic ladder, recommending the use of analgesic treatment in two steps, according to the degree of severity of the child's pain. This strategy consists of choosing the category of analgesic drugs according to the level of pain intensity in the child: for children evaluated with mild pain, paracetamol and ibuprofen should be considered as first options; whereas those evaluated with moderate to severe pain, the administration of an opioid should be considered.
The World Health Organization also recommends the use of non-pharmacological strategies, in line with the SCMP, which states that the pediatric pain trigger event is often closely associated with fear, anxiety, and stress ${ }^{17}$.

Among the most commonly used non-pharmacological measures, methods of distraction, relaxation and comfort can be mentioned; hot water bag, non-nutritive suction, affection, calming, recreational activities and informative conversation about pain. However, it was evident in this study that the organizational culture associated with the lack of empowerment on the part of professionals leads to choices of exclusively pharmacological measures for the relief of pediatric pain.

\section{CONCLUSION}

Nursing professionals are sensitive to pain relief, but just offering training on pain assessment instruments, although important, is not enough to achieve continuity of care and alleviate the pain of hospitalized children.

The achievement of adequate pain management depends directly on the articulation between intrinsic and extrinsic factors of the one who feels the pain and of the one who assists it, according to the assumptions of the Social Communication Model of Pain.

\section{REFERENCES}

1. IASP. Classification of chronic pain. Descriptions of chronic pain syndromes and definitions of pain terms Seattle: IASP Press; 1994;2:209-14.

2. Williams AC, Craig KD. Updating the definition of pain. Pain. 2016;157(11):2420-3.

3. Stevens BJ, Yamada J, Promislow S, Stinson J, Harrison D, Victor JC, et al. Implementation of multidimensional knowledge translation strategies to improve procedural pain in hospitalized children. Implement Sci. 2014;9:120.

4. Blasi DG, Candido LK, Tacla MT, Ferrari RA. Avaliaçấo e manejo da dor na criança: percepçáo da equipe de enfermagem. Semina Cienc Biol Saude. 2015;36(Suppl 1):301-10.

5. Araujo LC, Romero B. Pain: evaluation of the fifth vital sign. A theoretical reflection. Rev Dor. 2015;16(4):291-6.

6. Doca FN, Costa Júnior AL, Finley GA, Linhares MB. Pain in pediatric inpatients: prevalence, characteristics, and management. Psychol Neurosci. 2017;10(4):394-403.

7. Hampton AJD, Hadjistavropoulos T, Gagnon MM. Contextual influences in decoding pain expressions: effects of patient age, informational priming, and observer characteristics. Pain. 2018;159(11):2363-74.

8. Craig KD. The social communication model of pain. Can Psychol. 2009;50(1):22-32

9. Miftah R, Tilahun W, Fantahun A, Adulkadir S, Gebrekirstos K. Knowledge and factors associated with pain management for hospitalized children among nurses working in public hospitals in Mekelle City, North Ethiopia: cross sectional study. BMC Res Notes. 2017;10(1):122.

10. Minayo MCS. Pesquisa social: teoria, método e criatividade. $30^{\text {nd }}$ ed. Petrópolis, RJ: Vozes; 2016.

11. Silva JA. The challenge of pain. Psychol Neurosci. 2014;7(1):1-2.

12. Vale EG, Pagliuca LM. [Construction of a nursing care concept: contribution for undergraduate nursing education]. Rev Bras Enferm. 2011;64(1):106-13. Portuguese, English.

13. Carlino E, Benedetti F. Different contexts, different pains, different experiences. Neuroscience. 2016;53(1):19-26.

14. Sekhon KK, Fashler SR, Versloot J, Lee S, Craig KD. Children's behavioral pain cues: implicit automaticity and control dimensions in observational measures. Pain Res Manag. 2017;2017:3017837.

15. Candido LK, Tacla MT. Avaliação e caracterização da dor na criança: utilizaçáo de indicadores de qualidade. Rev Enferm UERJ. 2015;23(4):526-32.

16. Riddell RP, Racine NM, Craig KD, Campbell L. Psychological theories and biopsychosocial models in paediatric pain. In: McGrath P, Stevens B, Walker S, Zempsky W. Paediatric Pain. Oxford, $1^{\text {st }}$ ed. New York: Oxford University Press; 2018. 85-94p.

17. Health Organization. WHO guidelines on the pharmacological treatment of persisting pain in children with medical illnesses. Geneva, World Health Organization, 2012. 